\title{
The beneficial effects of Montelukast against 2,3,7,8-tetrachlorodibenzo-p-dioxin toxicity in female reproductive system in rats $^{1}$
}

\author{
Rauf Melekoglu', Osman Ciftci ${ }^{\mathrm{II}}$, Aslı Cetin ${ }^{\mathrm{III}}$, Nese Basak ${ }^{\mathrm{IV}}$, Ebru Celik \\ DOI: http://dx.doi.org/10.1590/S0102-865020160080000009 \\ IAssistant Professor, Department of Obstetrics and Gynaecology, Faculty of Medicine, University of Inonu, Malatya, Turkey. Acquisition of data, \\ manuscript writing. \\ IIAssociate Professor, Department of Medical Pharmacology, Faculty of Medicine, University of Inonu, Malatya, Turkey. Design of the study, \\ manuscript writing. \\ IIIAssistant Professor, Department of Histology, Faculty of Medicine, University of Inonu, Malatya, Turkey. Histological examinations. \\ ${ }^{\text {IV }} \mathrm{PhD}$, Department of Pharmaceutical Toxicology, Faculty of Pharmacy, University of Inonu, Malatya, Turkey. Biochemical examinations. \\ vAssociate Professor, Department of Obstetrics and Gynaecology, Faculty of Medicine, University of Inonu, Malatya, Turkey. Design of the study.
}

\section{ABSTRACT}

PURPOSE: To determine the toxic effect of 2,3,7,8-tetrachlorodibenzo- $p$-dioxin (TCDD) on reproductive system and the beneficial effects of Montelukast (ML) with histological and biochemical analysis.

METHODS: Rats were randomly divided into four equal groups (control, TCDD, ML and TCDD+ML). Tissue samples were collected on day 60 and oxidative status and histological alterations were analyzed.

RESULTS: The results showed a significant increase in oxidative and histological damage on uterine and ovarian tissues. Otherwise, the oxidative and histological damages caused by TCDD were prevented with ML treatment.

CONCLUSION: The toxic effects of 2,3,7,8-tetrachlorodibenzo- $p$-dioxin on female reproductive system were reversed with Montelukast treatment. Therefore, we claimed that ML treatment might be useful for TCDD toxicity.

Key words: Tetrachlorodibenzodioxin. Oxidative Stress. Leukotriene Antagonists. Ovary. Uterus. 


\section{Introduction}

Dioxins include a class of environmental contaminants that are primarily produced through industrial processes such as electronics recycling, power generation and the manufacture of herbicides and pesticides. The most potent dioxin is 2,3,7,8-tetrachlorodibenzo-p-dioxin (TCDD), which induces highly variable toxic responses among rodent species. Foods such as milk and milk products, bovine adipose tissue, hen's eggs and fish are the main contributors to human exposure of TCDD and other dioxins $^{1,2}$. TCDD plays a significant role for various toxic effects including carcinogenesis, wasting syndrome, immunotoxicity, hepatotoxicity, reproductive toxicity, teratogenicity and endocrine changes in experimental animals via their interaction with the aryl hydrocarbon receptor $(\mathrm{AhR})^{3}$. The AhR, a member of the family of basic helix-loop-helix transcription factors, binds several exogenous ligands such as natural plant flavonoids, polyphenolics and indoles, as well as synthetic polycyclic aromatic hydrocarbons and dioxin-like compounds ${ }^{3,4}$.Moreover, it was suggested that AhR can not be the only toxic mechanism of action for dioxins while oxidative stress has an important role for toxic effects of TCDD together with $\mathrm{AhR}^{4}$. TCDD has long been recognized as a prototypical disruptor in reproductive tissues. TCDD and related substances enhance the production of reactive oxygen species (ROS) in reproductive system. Besides, several studies demonstrated that exposure to TCDD leads to oxidative damage of many tissues such as liver, kidney and testis ${ }^{5,6}$. Based on these findings, antioxidant therapy may be beneficial against toxic effects of TCDD in terms of toxicity on uterus and ovaries.

Montelukast (ML) is an anti-inflammatory drug with potent antioxidant properties that directly interferes with leukotriene production and their receptors ${ }^{7}$. It is a selective reversible cysteinyl leukotriene D4 (LTD4) receptor antagonist. Therefore, oral treatment of ML has effect on the maintenance treatment of asthma and relieve symptoms of seasonal allergies in adults and children ${ }^{8}$. Several studies also showed that ML has a significant antioxidative effect on inhibition of lipid peroxidation in some tissues such as testis and liver ${ }^{9,10}$. Cuciureanu et al. ${ }^{11}$ demonstrated a partial hepatoprotective effect of montelukast against carbon tetrachloride induced hepatopathy on rats. However, there is no study on the therapeutic effect of this agent on over and uterus for oxidative damage caused by TCDD toxicity.

Aforementioned propositions, we thought that ML may prevent toxic effect of TCDD via their antioxidant properties. In this study, we aimed to determine the toxic effect of TCDD on uterine and ovarian tissues with histological and biochemical analysis. Besides, we inspected the contradictory effects of ML on TCDD toxicity on uterus and ovary.

\section{Methods}

Experiments were performed on the basis of animal ethics guidelines of the Inonu University Institutional Animals Ethics Committee (Ethical Committee Approval no: 2013/A-59).

A total of 28 healthy adult female Wistar albino rats (aged 3-4 months), obtained from The Experimental Animal Institute (Malatya, Turkey), were used for this experiment. Diet and drinking water for them were given ad libitum.

Rats were randomly divided into four equal groups as follow: Group 1: control, group 2 which exposed to TCDD, group 3 which exposed to ML, and group 4 which exposed to both TCDD and ML. Each group has 7 rats. Control group was orally fed by corn oil TCDD and ML, dissolved in corn oil, were orally administered at the dose of $2 \mathrm{mg} / \mathrm{kg} /$ week and $10 \mathrm{mg} / \mathrm{kg} /$ day for 60 days, respectively. In group 4, rats were exposed to both TCDD and ML (TCDD+ML group) at the equivalent doses. Tissue samples were collected on day 60 after TCDD and ML treatment. After the animals were euthanized under ether anesthesia, uterine and ovarian tissues were forthwith extracted and dissected over ice-cold glass.

\section{Chemicals}

TCDD (purity $>99 \%$ ) was obtained from Accustandart, Inc. (New Haven, Connecticut, USA). ML as Onceair was provided by Abdi Ibrahim drug company (Istanbul, Turkey). All other chemicals were purchased from Sigma Chemical Co. (St Louis, Missouri, USA) and were of analytical grade or of the highest grade available.

\section{Biochemical assay}

The homogenization of tissues was carried out in a Teflon glass homogenizer in $150 \mathrm{mM} \mathrm{KCl}(\mathrm{pH} 7.4)$ to obtain $1: 10$ $(w / v)$ dilution of the whole homogenate. The homogenates were centrifuged at $18.000 \mathrm{~g}\left(4^{\circ} \mathrm{C}\right)$ for $30 \mathrm{~min}$ and at $25.000 \mathrm{~g}$ for 50 min. The levels of TBARS, as an index of lipid peroxidation, were determined by thiobarbituric acid reaction by using the method of Yagi (1998) $)^{12}$. The product was assessed spectrophotometrically at $532 \mathrm{~nm}$ and the results were expressed as nanomoles per gram of tissue. The method of Sedlak and Lindsay ${ }^{13}$ was used to determine the reduced glutathione (GSH) content of the kidney homogenate 
at $412 \mathrm{~nm}$. The results were expressed as nanomoles per milliliter tissue. Copper-zinc superoxide dismutase (SOD) activity was measured by the inhibition of nitroblue tetrazolium reduction as a result of $\mathrm{O}_{2}$ generation by the xanthine/xanthine oxidase system ${ }^{14}$. The results of product, which were evaluated at $560 \mathrm{~nm}$ were expressed as units per milligram protein. Catalase (CAT) activity of tissues was measured in accordance with the method of Aebi ${ }^{15}$. The enzymatic decomposition of $\mathrm{H}_{2} \mathrm{O}_{2}$ was monitored literally by the decrease in absorbance at $240 \mathrm{~nm}$. The enzyme activities were expressed as $\mathrm{k} / \mathrm{mg}$ protein. The method established by Lowry et $a l .{ }^{16}$ using bovine serum albumin as standard was used for the determination of tissue protein content.

\section{Histological analysis}

For light microscopic evaluation, ovarian and uterine samples were fixed in $10 \%$ formalin and were embedded in paraffin. Paraffin-embedded specimens were cut into $5 \mu \mathrm{m}$ thick sections, mounted on slides and stained with Hematoxylen-Eosin (H-E). Tissue samples were examined using a Leica DFC280 light microscope and a Leica Q Win Image Analysis system (Leica Micros Imaging Solutions Ltd., Cambridge, UK).

\section{Statistical analysis}

All values were presented as mean \pm SD Differences were considered to be significant at $\mathrm{p}<0.01$. A computer program SPSS 18.0 (SPSS Inc., Chicago, IL, USA) was used for statistical analysis. For biochemical values, statistical analyses were performed using one-way ANOVA and post hoc Tukey's honestly significant difference test. Histological results were compared with Kruskal-Wallis variance analysis. Where differences among the groups were detected, group means were compared using the Mann-Whitney U test.

\section{Results}

\section{Biochemical results}

The antioxidant (SOD, CAT, and GSH) and oxidant parameters (TBARS) in rats uterus and ovary were presented in Tables 1 and 2, respectively. A significant elevation in TBARS levels was observed in the group exposed to TCDD whereas GSH levels and SOD and CAT activity significantly declined in uterine and ovarian tissues compared to the other groups. There were also no statistically significant differences between the control and ML groups regarding to TBARS, SOD, CAT, and GSH levels. Otherwise, decline in TBARS levels and increment in SOD and CAT activities and GSH levels in the group exposed to both TCDD and ML were observed in comparison to the group exposed to only TCDD. Administration of these substances together with TCDD improved SOD, CAT, GSH, and TBARS levels which were closer to the control level.

TABLE 1 - The levels of SOD, CAT, GSH and TBARS in rat uterus tissue. $\pm \mathrm{SD}$

\begin{tabular}{ccccc}
\hline & $\begin{array}{c}\text { TBARS } \\
\text { (nmol/g } \\
\text { tissue) }\end{array}$ & $\begin{array}{c}\text { Reduced } \\
\text { GSH nmol/ } \\
\mathrm{ml}\end{array}$ & $\begin{array}{c}\text { CAT kU/ } \\
\text { mg protein }\end{array}$ & $\begin{array}{c}\text { SOD (U/mg } \\
\text { protein) }\end{array}$ \\
\hline Control & $5.18 \pm 1.12^{\mathrm{a}}$ & $151.7 \pm 18.1^{\mathrm{a}}$ & $1.23 \pm 0.09^{\mathrm{a}}$ & $18.12 \pm 3.17^{\mathrm{a}}$ \\
TCDD & $8.93 \pm 1.21^{\mathrm{b}}$ & $104.8 \pm 11.2^{\mathrm{b}}$ & $0.96 \pm 0.05^{\mathrm{b}}$ & $10.01 \pm 1.14^{\mathrm{b}}$ \\
ML & $5.75 \pm 1.35^{\mathrm{a}}$ & $162.5 \pm 16.8^{\mathrm{a}}$ & $1.25 \pm 0.08^{\mathrm{a}}$ & $16.52 \pm 1.82^{\mathrm{a}}$ \\
TCDD+ & $6.51 \pm 0.97^{\mathrm{c}}$ & $131.6 \pm 21.1^{\mathrm{c}}$ & $1.03 \pm 0.09^{\mathrm{b}}$ & $13.15 \pm 2.23^{\mathrm{a}}$ \\
ML & & & &
\end{tabular}

SOD; superoxide dismutase; CAT: catalase; GSH: glutathione, TBARS: thiobarbituric acid reactive substance; ML: montelukast; TCDD: 2,3,7,8-tetrachlorodibenzo-p-dioxin.

Means bearing different superscripts within same column were significantly different $(\mathrm{p}<0.01)$.

TABLE 2 - The levels of SOD, CAT, GSH and TBARS in rat ovarium tissue. \pm SD.

\begin{tabular}{ccccc}
\hline & $\begin{array}{c}\text { TBARS } \\
\text { (nmol/g } \\
\text { tissue) }\end{array}$ & $\begin{array}{c}\text { Reduced } \\
\text { GSH nmol/ } \\
\mathrm{ml}\end{array}$ & $\begin{array}{c}\text { CAT kU/ } \\
\text { mg protein }\end{array}$ & $\begin{array}{c}\text { SOD (U/mg } \\
\text { protein) }\end{array}$ \\
\hline $\begin{array}{c}\text { Control } \\
\text { TCDD }\end{array}$ & $\begin{array}{c}6.13 \pm 0.92^{\mathrm{a}} \\
10.05 \pm 1.75^{\mathrm{b}}\end{array}$ & $121.4 \pm 21.4^{\mathrm{b}}$ & $0.66 \pm 0.08^{\mathrm{b}}$ & $14.18 \pm 3.41^{\mathrm{b}}$ \\
ML & $6.88 \pm 1.42^{\mathrm{a}}$ & $171.8 \pm 27.5^{\mathrm{a}}$ & $1.01 \pm 0.09^{\mathrm{a}}$ & $24.10 \pm 5.21^{\mathrm{a}}$ \\
$\begin{array}{c}\text { TCDD } \\
+ \text { ML }\end{array}$ & $7.28 \pm 1.22^{\mathrm{a}}$ & $158.4 \pm 19.5^{\mathrm{ac}}$ & $0.84 \pm 0.09^{\mathrm{c}}$ & $21.85 \pm 3.12^{\mathrm{a}}$ \\
\hline
\end{tabular}

ML: montelukast; TCDD: 2,3,7,8-tetrachlorodibenzo-p-dioxin.

Means bearing different superscripts within same column were significantly different $(\mathrm{p}<0.01)$.

\section{Histological results}

There were significant differences in the uterine and ovarian morphology among the treatment groups. In control ovarian tissue (Figure $1 \mathrm{~A}-\mathrm{C}$ ) and $\mathrm{ML}$ (Figure $4 \mathrm{~A}-\mathrm{C}$ ) groups, ovaries showed normal histological appearance. Different follicle types and corpus luteum were observed in ovary. Multilaminary (Figure 1A) and secondary (Figure 1 B,C) follicles were observed in control group. Secondary follicles (Figure 4A), unilaminary 
primary follicles (Figure 4B) and graffian follicles (Figure 4C) were observed in ML group. A histopathological examination revealed some degenerative ovarian follicles in TCDD group. In TCDD group, we detected significantly higher scores for follicular degeneration (Figure 2 A,C,E), vascular congestion (Figure 2 A,C), edema, hemorrhage (Figure $2 \mathrm{~A}, \mathrm{C}, \mathrm{F}$ ) and mononuclear cell infiltration (Figure $2 \mathrm{~A}-\mathrm{F}$ ). The administration of both TCDD and ML showed a significant level of improvement in ovarian follicle morphology, edema, mononuclear cell infiltration, vascular congestion and hyperemia as compared with the TCDD group. Multilaminary primary follicles (Figure 3C) and developed corpus luteum (Figure $3 \mathrm{~A}, \mathrm{~B}$ ) were observed in this group.

In control group, the uterine lumen is lined by tall columnar epithelium (Figure 5A) with oval nucleus. The endometrial epithelium was evaluated in all groups using light microscope. We detected normal endometrial epithelium in control (Figure 5A) and ML groups (Figure 5D), thin endometrial epithelium in TCDD group (Figure 5B). In addition to this, we detected degenerative stromal glands and mononuclear cell infiltration in endometrial stroma. In TCDD group, profusely expansion of blood vessels area were observed. We observed improvement in epithelial appearance in the group exposed to both TCDD and ML (Figure 5C).
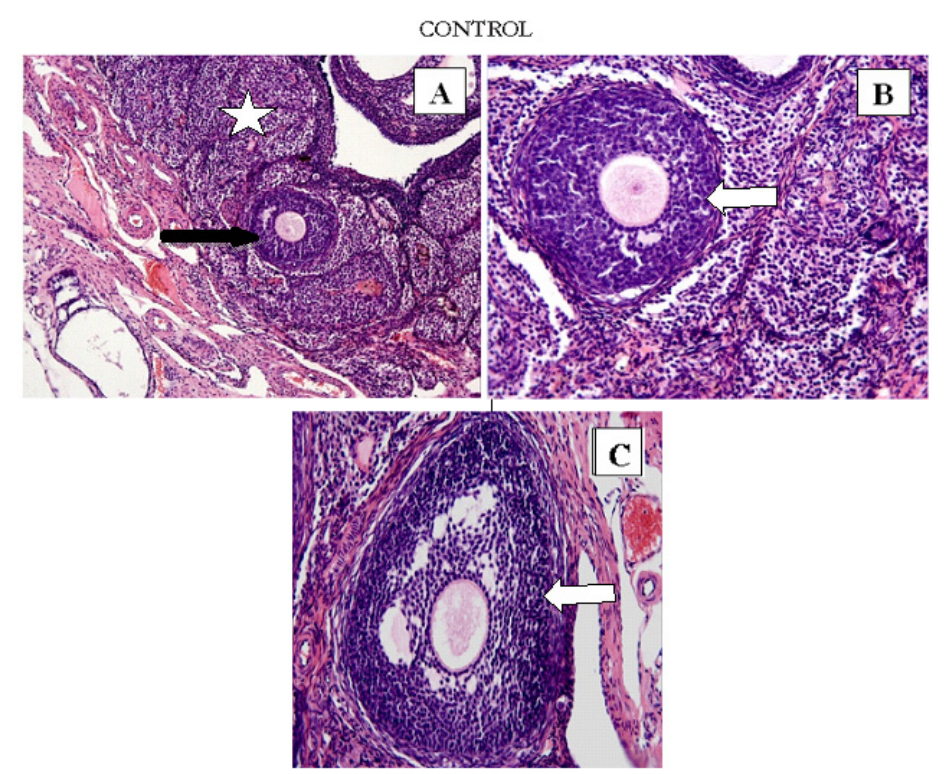

FIGURE 1 - Ovaries from control rats showing normal histological appearance. Different follicles types $(\mathrm{A}, \mathrm{B}, \mathrm{C})$ and corpus luteum (white star) (A) were observed in ovary. Multilaminary (black arrow) (A) Secondary (white arrows) $(\mathrm{B}, \mathrm{C})$ follicles were observed in control group. (A: H-E; x10, B, C: H-E; x20)
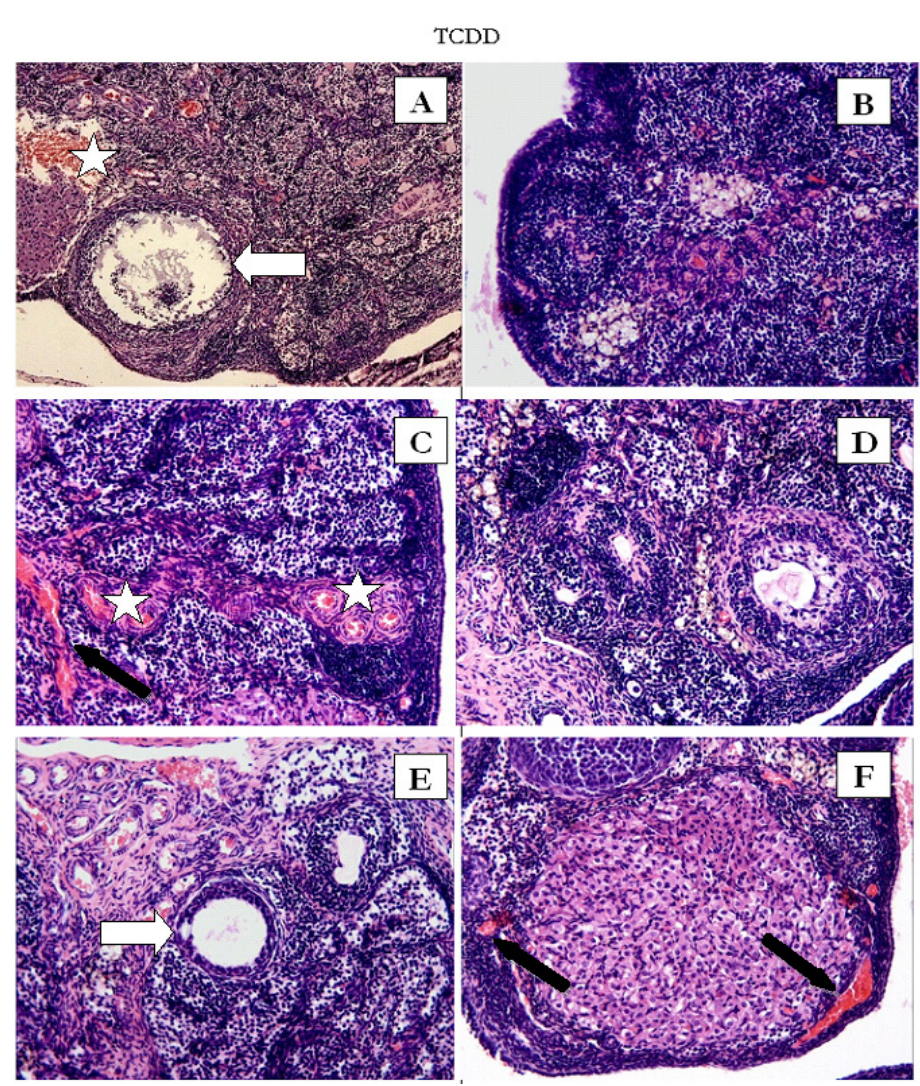

FÍGURE 2 - In TCDD group, we detected significantly higher scores for follicular degeneration (white arrows) (A,C,E), vascular congestion (white stars) (A,C), edema, hemorrhage (black arrows) $(\mathrm{A}, \mathrm{C}, \mathrm{F})$ and mononuclear cell infiltration (A-F). (A: H-E; x10, B,C,D,E,F: H-E; x20)
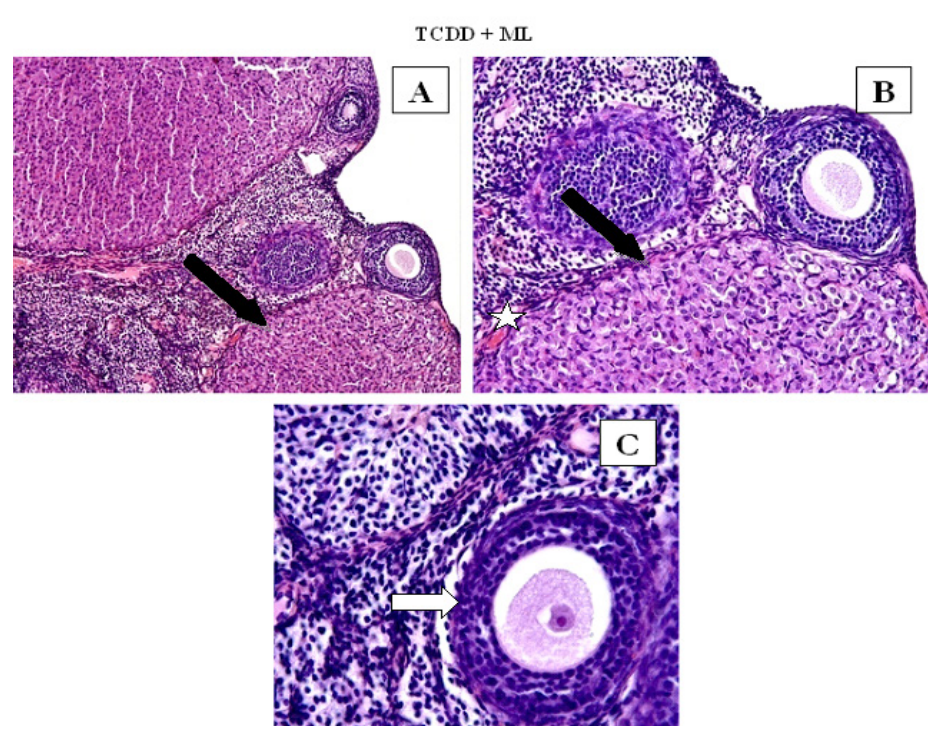

FÍGURE 3 - In TCDD + ML group showed a significant level of improvement in ovarian follicle morphology, edema, mononuclear cell infiltration, vascular congestion (white star) (B) and hyperemia as compared with the TCDD group. Multilaminary primary follicles (white arrow) (C) and improved corpus luteum (black arrows) $(\mathrm{A}, \mathrm{B})$ were observed in this group. (A: H-E; x10, B: H-E; x20, C: H-E; x40) 


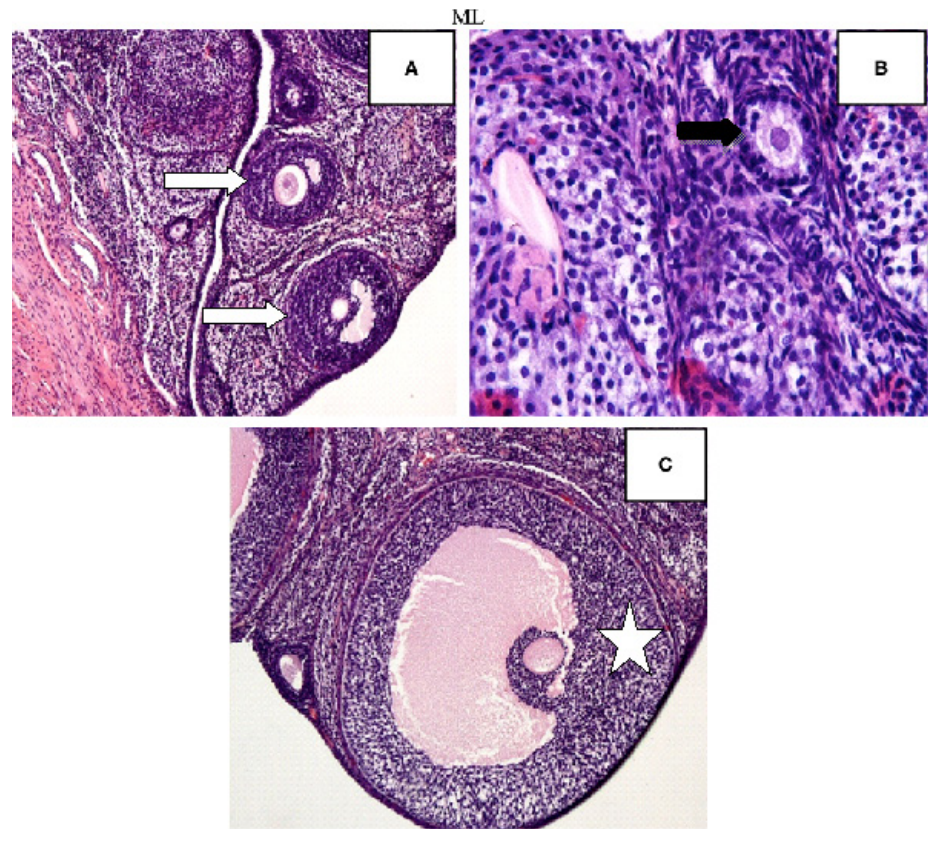

FİGURE 4 - Normal histological appearance were observed in ML group. Secondary follicles (white arrows) (A), unilaminary primary follicle (black arrow) (B) and graffian follicles (white star) (C) were observed in ML group. (A: H-E; x10, B: H-E; x40, C: H-E; x20)

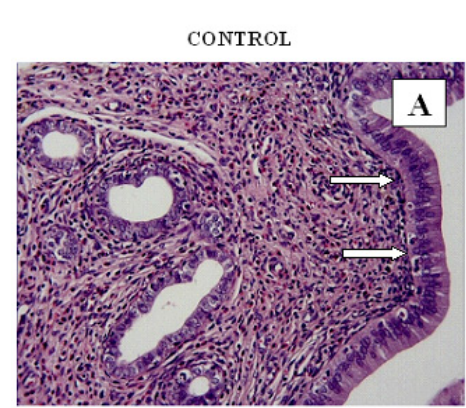

$\mathrm{TCDD}+\mathrm{ML}$

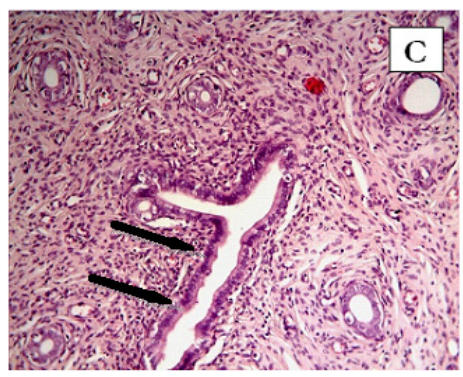

FIGURE 5 - Normal endometrial epithelium (white arrows) in control (A) and ML (D) groups, thin endometrial epithelium (black arrows) in TCDD group (B). We observed improvement in epithelial appearance (thin black arrows) in TCDD + ML group (C). (A-D: H-E; x20)

\section{Discussion}

Numerous natural and synthetic chemicals can interfere with the female reproductive system in mammals such as anovulation, reduced conception rates, abortion, menstrual abnormalities, developmental defects of reproductive tissues and rise in incidence of reproductive tract disorders ${ }^{17}$. Tetrachlorodibenzo-p-dioxin (TCDD) is the most potent toxic agent on reproductive system among these chemicals. In humans and animals, the ingestion of contaminated food or water is the main source of exposure to TCDD ${ }^{18}$. In this study, we demonstrated a significant elevation in oxidative stress markers and a significant decline in antioxidant defense systems in uterine and ovarian tissues by TCDD exposure. Additionally, it was observed that ML treatment potentially interfered with the toxic effects of TCDD.

\section{TCDD toxicity on uterine and ovarian tissues}

Oxidative stress is a condition of an imbalance between the free radicals and antioxidant defense system which leads to lipid peroxidations and inactivation of many enzymes. The antioxidant system protects cells against damage induced by free radicals such as superoxide anion and hydrogen peroxide. In this study, it was showed that TCDD lead to disrupted antioxidative balanced with a significant decline in SOD, CAT and GSH levels. On the other hand, TBARS levels significantly increased with TCDD treatment, which is associated with cell damage in uterine and ovarian tisues. In parallel, recent studies observed that environmental toxicants adversely affect ovarian function and fertility ${ }^{19,20}$. Chen et al. ${ }^{21}$ performed proteomic analysis of the ovaries by two-dimensional gel electrophoresis and matrix-assisted laser desorption/ionization tandem mass spectrometry and showed distinct changes in the levels of several proteins that are relevant markers of TCDD toxicity. Valdez et $a l .{ }^{22}$ revealed that TCDD exposure cause the failure of ovarian function via alteration of ovarian gene expression. The mechanism underlying the aforementioned disorders occurred as a consequence of TCDD exposure may be related to estrogenic/ anti-estrogenic effects, regulation of sex-steroid metabolism, and an increase in the proteosomal degradation of receptors. Although these mechanisms and their combinations may partially explain the adverse effects of TCDD on reproductive and development, it is yet completely understood by which these mechanisms contribute to the negative impact ${ }^{23}$. The other major toxic influence of TCDD on reproductive system is the enhanced ROS production. In this study, we assumed that the toxic mechanism of TCDD is correlated with ROS production regarding to an increase of TBARS and a decrease of SOD, CAT and GSH. Our findings are parallel to the previous studies observations ${ }^{24,25}$, that confirming our results.

\section{The beneficial effects of $M L$}

The antioxidant remedy may have beneficial effects on opposing to several adverse outcome of chemical toxicants 
concomitant to organ damage. In this study, we showed that ML, a LT4 antagonist drug, prohibits the detrimental event of TCDD on uterine and ovarian tissues through its antioxidant aspects. When administration of ML incombination with TCDD induce to a reduction in the elevated TBARS levels and enhancement of SOD, CAT and GSH levels as a consequence of TCDD exposition. Thus, we claimed that administration of ML may preserve tissues from destructive results of TCDD. In accordance, Koga et al. ${ }^{26}$ conducted a study on the effects of four anti-oxidants on reduced the fetal expression of steroidogenic proteins and gonadotropins, produced by TCDD. The anti-oxidants include two endogenous substances [a-lipoic acid (LA) and ascorbic acid (VC)], a drug acting as a radical scavenger (edaravone), and a classical anti-oxidant [3-tertbutyl-4- hydroxyanisole (BHA)]. During the course of their study, only LA has the ability to restore a TCDD-induced reduction in the expression of fetal testicular steroidogenic proteins was observed, whereas the other anti-oxidants not. Latchoumycadane et al. ${ }^{27}$ suggested that administration of TCDD induces oxidative stress in testis, and vitamin E could provide a protective effect opposed to TCDD-induced oxidative stress. Bentli et al. ${ }^{28}$ found that the use of ML in combination with TCDD minimized its hepatatotoxic effect via determination of oxidative stress and histological alterations in liver tissue, and serum cytokine diversity in rats. All of previous studies showed that the antioxidant medication with various antioxidative substances prevented detrimental effects of TCDD with their antioxidative actions. These findings supported our results, which revealed that ML may capable to reverse the toxic effect of TCDD.

\section{Histopatlogical examination}

The present study showed that TCDD treatment caused severe histological damages, including degeneration of ovarian follicles, higher scores for follicular impairment, vascular congestion, edema, hemorrhage and mononuclear cell infiltration in ovarian tissues. Besides, it was observed that TCDD promoted degenerative stromal glands and mononuclear cell infiltration in endometrial stroma of uterine tissues. On the other hand, ML administration accompanying to TCDD restricted the preceding adverse effects of TCDD on ovarian and uterine tissues. Yet, we are not aware of any study on effects of ML on the ovarian and uterine tissues. In literature, it was shown that similar antioxidants such as vitamin $\mathrm{E}$, vitamin $\mathrm{C}$ and beta-caratone protects uterine and ovarian tissues from oxidative injuries to uterine and ovarian tissues $^{29,30}$. Guney et al. ${ }^{29}$ demonstrated reduced lymphocyte and eosinophil infiltration in endometrial stroma by vitamins $\mathrm{C}$ and
E treatment in fluoride toxicity. Aksak et al. ${ }^{30}$ observed betacarotene provides a partial recovery on intense hemorrhagic areas in the cortex, necrotic cells in the medulla and PMNL adhesion to vascular endothelia in ischemia-reperfusion models of rat ovaries. These results are in accordence with our findings. It was speculated that the uterine and ovarian damage was as a consequence of oxidative stress, which was correlated with histological damage. Therefore, the beneficial effects of ML on uterine and ovarian tissues as well as oxidative stress may arise due to its antioxidant properties and binding AhR receptors.

\section{Conclusion}

The toxic effects of 2,3,7,8-tetrachlorodibenzo-p-dioxin (TCDD) on female reproductive system were reversed with Montelukast (ML) treatment. Therefore, we claimed that ML treatment might be useful for TCDD toxicity.

\section{References}

1. Prokopec SD, Buchner NB, Fox NS, Chong LC, Mak DY, Watson JD, Petronis A, Pohjanvirta R, Boutros PC. Validating reference genes within a mouse model system of 2,3,7,8-tetrachlorodibenzo-pdioxin (TCDD) toxicity. Chem Biol Interact. 2013 Sep 5;205(1):6371. doi: 10.1016/j.cbi.2013.06.008.

2. Ciftci O, Tanyıldızı S, Godekmerdan A. Protective effect of curcumin on immune system and body weight gain on rats intoxicated with 2,3,7,8-Tetrachlorodibenzo-p-dioxin (TCDD). Immunopharmacol Immunotoxicol. 2010;32(1):99-104. doi: 10.3109/08923970903164318.

3. Ciftci O, Ozdemir I, Vardi N, Beytur A, Oguz F. Ameliorating effects of quercetin and chrysin on 2,3,7,8-tetrachlorodibenzo- p-dioxininduced nephrotoxicity in rats. Toxicol Ind Health. 2012;28(10):94754. doi: 10.1177/0748233711430978.

4. Turkez H, Geyikoglu F, Yousef MI. Ameliorative effect of docosahexaenoic acid on 2,3,7,8-tetrachlorodibenzo-p-dioxininduced histological changes, oxidative stress, and DNA damage in rat liver. Toxicol Ind Health. 2012;28(8):687-96. doi: 10.1177/0748233711420475.

5. Ciftci O, Aydin M, Ozdemir I, Vardi N. Quercetin prevents 2,3,7,8-tetrachlorodibenzo-p-dioxin-induced testicular damage in rats. Andrologia. 2011;44(3):164-73. doi: 10.1111/j.14390272.2010.01126.x.

6. Slezak BP, Hatch GE, Devito MJ, Diliberto JJ, Slade R, Crissman $\mathrm{K}$, Hassoun E, Burnbaum LS. Oxidative stress in female B6C3F1 mice following acute and subchronic exposure to 2, 3,7,8tetrachlorodibenzo-p-dioxin (TCDD). Toxicol Sci. 2000;54(2):390 8. PMID: 1077482.

7. Muthuraman A, Sood S. Antisecretory, antioxidative and antiapoptotic effects of montelukast on pyloric ligation and water immersion stress induced peptic ulcer in rat. Prostaglandins Leukot Essent Fatty Acids. 2010;83(1):55-60. doi: 10.1016/j. plefa.2010.01.003.

8. Canbay E, Agachan B, Ozturk T, Giris M, Asoglu O, Balik E, Bugra D. Dual inhibition of wound healing and oxidative process by montelukast in experimental colon anastomoses. Surg Innov. 2010;17(3):248-55. doi: 10.1177/1553350610376393. 
9. Kose E, Sapmaz HI, Sarihan E, Vardi N, Turkoz Y, Ekinci N. Beneficial effects of montelukast against methotrexate-induced liver toxicity: a biochemical and histological study. Sci World J. 2012;2012:987508. doi: 10.1100/2012/987508.

10. Beytur A, Ciftci O, Oguz F, Oguzturk H, Yilmaz F. Montelukast attenuates side effects of cisplatin including testicular, spermatological, and hormonal damage in male rats. Cancer Chemother Pharmacol. 2012;69(1):207-13. doi: 10.1007/s00280011-1692-y.

11. Cuciureanu M, Ca runtu ID, Pa duraru O, Stoica B, Jerca L, Crauciuc E, Nechifor M. The protective effect of montelukast sodium on carbon tetrachloride induced hepatopathy in rat. Prostaglandins Other Lipid Med. 2009;88(3-4):82-8. doi: 10.1016/j. prostaglandins.2008.10.004.

12. Yagi K. Simple assay for the level of total lipid peroxides in serum or plasma. Methods Mol Biol. 1998;108:101-6. PMID: 9921519.

13. Sedlak J, Lindsay RH. Estimation of total, protein bound, and nonprotein sulfhydryl groups in tissue with Ellman's reagent. Anal Biochem. 1968;25(1):192-205. PMID: 4973948.

14. Sun Y, Oberley LW, Li YA. Simple method for clinical assay of superoxide dismutase. Clin Chem. 1988;34(3):497-500. PMID: 3349599.

15. Aebi H. Catalase. In: Methods of enzymatic analysis. Bergmeyer HU (ed). New York: Academic Press; 1974. p.673-7.

16. Lowry $\mathrm{OH}$, Rosebrough NJ, Farr AL, Randall RI. Protein measurement with folin phenol reagent. J Biol Chem. 1951;193(1):265-75. PMID: 14907713.

17. Hombach-Klonisch S, Pocar P, Kietz S, Klonisch T. Molecular actions of polyhalogenated arylhydrocarbons (PAHs) in female reproduction. Curr Med Chem. 2005;12(5):599-616. PMID: 15777215.

18. Ferna 'ndez-Gonza 'lez R, Yebra-Pimentel I, Mart 'inez-Carballo E, Simal-Ga ndara J. A critical review about the human exposure to polychlorinated dibenzo-p-dioxins (PCDDs), polychlorinated dibenzofurans (PCDFs) and polychlorinated biphenyls (PCBs) through foods. Crit Rev Food Sci Nutr. 2015;55(11):1590-617. doi: 10.1080/10408398.2012.710279.

19. Newbold RR. Lessons learned from perinatal exposure to diethylstilbestrol. Toxicol Appl Pharmacol. 2004;199(2):142-50. PMID: 15313586

20. Li X, Johnson DC, Rozman KK. Reproductive effects of 2,3,7,8-tetrachlorodibenzo-p-dioxin (TCDD) in female rats: ovulation, hormonal regulation, and possible mechanism(s). Toxicol Appl Pharmacol. 1995;133(2):321-7. PMID: 7645029.

21. Chen X, Ma XM, Ma SW, Coenraads PJ, Zhang CM, Liu J, Zhao LJ, Sun M, Tang NJ. Proteomic analysis of the rat ovary following chronic low-dose exposure to 2,3,7,8-tetrachlorodibenzo-p-dioxin (TCDD). J Toxicol Environ Health A. 2009;72(11-12):717-26. doi: $10.1080 / 15287390902841136$

22. Valdez KE, Shi Z, Ting AY, Petroff BK. Effect of chronic exposure to the aryl hydrocarbon receptor agonist 2,3,7,8-tetrachlorodibenzop-dioxin in female rats on ovarian gene expression. Reprod Toxicol. 2009;28(1):32-7. doi: 10.1016/j.reprotox.2009.03.004.
23. Ohtake F, Takeyama K, Matsumoto T, Kitagawa H, Yamamoto Y, Nohara K, Tohyama C, Krust A, Mimura J, Chambon P, Yanagisawa J, Fujii-Kuriyama Y, Kato S. Modulation of oestrogen receptor signaling by association with the activated dioxin receptor. Nature. 2003;423(6939):545-50. PMID: 12774124.

24. Stohs SJ, Hassen MQ, Murray WJ. Lipid peroxidation as a possible cause of TCDD toxicity. Biochem Biophys Res Commun. 1983;111(3):854-9. PMID: 6838590.

25. Ishida T, Hori M, Ishii Y, Oguri K, Yamada H. Effects of dioxins on stress-responsive systems and their relevance to toxicity. J Dermatol Sci. 2005;1(1):S105-12. doi: 10.1016/j.descs.2005.03.011.

26. Koga $T$, Ishida $T$, Takeda $T$, Ishii $Y$, Uchi $H$, Tsukimori $K$, Yamamoto M, Himeno M, Furue M, Yamada H. Restoration of dioxin-induced damage to fetal steroidogenesis and gonadotropin formation by maternal cotreatment with $\alpha$-lipoic acid. PLoS One. 2012;7(7):e40322. doi: 10.1371/journal.pone.0040322.

27. Latchoumycadane $\mathrm{C}$, Chitra $\mathrm{C}$, Mathur P. Effects of vitamin $\mathrm{E}$ on reactive oxygen species-mediated 2,3,7,8-tetrachlorodibenzo-pdioxin toxicity in rat testis. J Appl Toxicol. 2002;22(5): 345-51. PMID: 12355564.

28. Bentli R, Ciftci O, Cetin A, Otlu A. Anti-inflamattory Montelukast prevents toxic effects of 2,3,7,8-tetrachlorodibenzo-p-dioxin: oxidative stress, histological alterations in liver, and serum cytokine levels. Toxicol Ind Health. 2016 May;32(5):769-76. doi: $10.1177 / 0748233713505894$.

29. Guney M, Oral B, Demirin H, Karahan N, Mungan T, Delibas N. Protective effects of vitamins $\mathrm{C}$ and $\mathrm{E}$ against endometrial damage and oxidative stress in fluoride intoxication. Clin Exp Pharmacol Physiol. 2007 May-Jun;34(5-6):467-74. PMID: 17439417.

30. Aksak Karamese S, Toktay E, Unal D, Selli J, Karamese M, Malkoc I. The protective effects of beta-carotene against ischemia/ reperfusion injury in rat ovarian tissue. Acta Histochem. 2015 Oct;117(8):790-7. doi: 10.1016/j.acthis.2015.07.006.

\section{Correspondence:}

Dr. Osman Ciftci

Department of Pharmacology, University of Inonu

44280 Malatya, Turkey

Phone: +905325646122

Fax: +90422 3411216

osmciftci@gmail.com

Received: Apr 04, 2016

Review: Jun 07, 2016

Accepted: July 11, 2016

Conflict of interest: none

Financial source: none

${ }^{1}$ Research performed at Experimental Animal Institute, University of Inonu, Malatya, Turkey. 